\title{
Hubungan Imunoekspresi CD34 dengan Gradasi dan Stadium (Duke) pada Adenokarsinoma Kolorektal
}

\author{
Herry Yulianti, Bethy S. Hernowo \\ Departemen Patologi Anatomi Fakultas Kedokteran Universitas Padjadjaran \\ Rumah Sakit Dr. Hasan Sadikin Bandung
}

\begin{abstract}
Abstrak
Karsinoma kolorektal umum terjadi di Eropa Barat Laut dan Amerika Utara, tetapi rendah di Afrika, Asia, dan Amerika Selatan. Di Indonesia, karsinoma kolorektal merupakan masalah kesehatan masyarakat dan merupakan tiga penyakit kanker terbanyak. Angiogenesis adalah pertumbuhan dan proliferasi pembuluh darah baru dari pembuluh darah yang sudah ada. Secara imunohistokimia, mikrovaskular dapat diidentifikasi dengan menggunakan monoklonal cluster of differentiation (CD34) antibodi. Pada beberapa penelitian, microvascular density (MVD) berhubungan dengan gradasi histologi, stadium, metastasis, dan prognosis tumor. Tujuan penelitian ini untuk mengetahui hubungan ekspresi CD34 dengan gradasi dan stadium (klasifikasi Duke) pada karsinoma kolorektal. Metode penelitian adalah cross sectional terhadap 40 kasus adenokarsinoma kolorektal yang berasal dari Departemen Patologi Anatomi Rumah Sakit Dr. Hasan Sadikin Bandung-Fakultas Kedokteran Universitas Padjadjaran tahun 2004-2005. Potongan blok parafin dari jaringan kolorektal karsinoma diwarnai dengan hematoksilin eosin untuk evaluasi histologi dan imunohistokimia menggunakan monoclonal CD34 antibody. Penghitungan MVD yang imunoreaktif dilakukan di bawah mikroskop cahaya dengan pembesaran 400x, dihitung rata-rata pada 5 tempat daerah neovaskularisasi yang paling padat. Hasil penelitian menunjukkan hubungan yang signifikan MVD dengan stadium $(\mathrm{p}<0,01)$ dan tidak ada hubungan yang signifikan antara MVD dan gradasi $(\mathrm{p}<0,05)$. Simpulan, hubungan MVD dengan kedalaman invasi dan metastasis ke kelenjar limfe yang dinilai dengan klasifikasi Duke dan CD34 dapat digunakan untuk memprediksi prognosis, memperkirakan kemungkinan metastasis melalui pembuluh darah, dan memprediksi respons terhadap terapi antiangiogenik. [MKB. 2013;45(4):240-4]
\end{abstract}

Kata kunci: Adenokarsinoma kolorektal, CD34, gradasi, klasifikasi Duke

\section{Correlation between CD34 Immunoexpression and Colorectal Adenocarcinoma Grade and Stage (Duke)}

\begin{abstract}
Carcinoma colorectal is commonly found in Nortwest Europe and North America, but not frequently found in Africa, Asia and South America. Colorectal cancer (CRC) is a public health problem in Indonesia and currently ranks among the three most common cancers. Angiogenesis is the growth and proliferation of new blood vessels from existing vasculature. Microvessels were identified immunohistochemically using monoclonal cluster of differentiation (CD34) antibody. Several studies have noted that microvascular density (MVD) correlates with stage of disease, histological grade, metastasis, and prognosis in cancers. The aim of this study was to explore the relation between CD34 immunoexpresion and grade and stage (Duke classification) in colorectal adenocarcinoma. This is a cross sectional study with 40 colorectal carcinoma cases from Department of Pathology Anatomy, Dr. Hasan Sadikin General Hospital/Faculty of Medicine, Universitas Padjadjaran Bandung during 2004-2005. A section from paraffin embedded tissue of colorectal carcinoma was stained with hematoxylin eosin for histological and immunohistochemical evaluations using monoclonal CD34 antibody. Microvascular density was counted in five tumor areas with most intensive neovascularization using 400x field light microscopy. A significant correlation was found between the MVD and stage $(p<0.01)$ while no significant relationship found between MVD and different grade $(\mathrm{p}<0.05)$. In conclusion, correlations are found between MVD with tumor invation depth and lymph node metastases determined by the Duke' staging system and CD34 can be used to predict prognosis, possibility of hematogenous metastases and responses to antiangiogenic therapy. [MKB. 2013;45(4):240-4]
\end{abstract}

Key words: Adenocarcinoma colorectal, CD34, Duke clasification, grade

Korespondensi: Herry Yulianti, dr., Sp.PA, Jalan Guntursari III no 21 Buah Batu Bandung (40264), Telepon (022)7310164 mobile 0811223103 e-mail herryyulianti@yahoo.com 


\section{Pendahuluan}

Karsinoma kolorektal secara umum terjadi di Eropa dan Amerika Utara, tetapi rendah di Afrika, Asia serta Amerika Selatan, ${ }^{1}$ dan merupakan penyakit kanker nomor tiga terbanyak di dunia setelah kejadian kanker paru dan payudara, ${ }^{2,3}$ juga penyebab kematian nomor dua di Amerika. ${ }^{4-6}$ Di Indonesia, karsinoma kolorektal merupakan masalah kesehatan masyarakat dan merupakan 3 (tiga) penyakit kanker terbanyak. ${ }^{3}$ Sebagian besar keganasan di kolorektal (98\%) merupakan adenokarsinoma. ${ }^{7}$ Derajat atau Grading adenokarsinoma kolorektal itu berdasarkan gambaran struktur kelenjar dan terbagi atas well, moderately, dan poorly differentiated. ${ }^{1,7}$ Untuk pertumbuhan dan metastasis adenokarsinoma itu diperlukan proses angiogenesis, yaitu proses pembentukan pembuluh darah baru yang dapat dideteksi dengan menggunakan monoklonal antibodi anti cluster of differentiation (CD)34., ${ }^{1,-12}$ Angiogenesis adalah pertumbuhan dan proliferasi pembuluh darah dari pembuluh darah yang sudah ada. ${ }^{13-15}$ Angiogenesis menentukan tahapan progresivitas tumor yang solid, hal ini telah diteliti pada beberapa tumor solid seperti colorectal, non small cell lung, hapatocelullar, melanoma, prostat, breast, dan juga bladder carcinoma. ${ }^{14,18}$ Microvessel density (MVD) merupakan jumlah pembuluh darah dihitung berdasarkan/unit area atau per lapang pandang. ${ }^{5}$ Terdapat hubungan angiogenesis itu dengan prognosis dan metastasis hematogen. ${ }^{4-6,10,15,17-19}$

Cluster of differentiation (CD) 34 merupakan suatu surface glycoprotein-human hematopoetic progenitor cell antigen yang terekspresi dan terdeteksi pada vascular endothelium dengan memakai monoklonal antibodi anti-CD34. ${ }^{13,20}$ Tujuan penelitian ini untuk mengetahui hubungan ekspresi CD34 dengan gradasi dan juga stadium (Duke) pada adenokarsinoma kolorektal.

\section{Metode}

Bentuk penelitian adalah cross sectional terhadap 40 kasus adenokarsinoma kolorektal yang terpilih dari pemeriksaan hematoxylin-eosin (HE) yang didiagnosis sebagai adenokarsinoma kolorektal yang berasal dari Departemen Patologi Anatomi Rumah Sakit (RS) Dr. Hasan Sadikin/Fakultas Kedokteran Universitas Padjadjaran Bandung, mulai bulan Januari 2004-Desember 2005.

Grading adenokarsinoma kolorektal dibagi ke dalam well differentiated jika sel sel tumor yang membentuk struktur kelenjar $>95 \%$, moderately differentiated jika struktur kelenjar 50-95\%, dan poorly differentiated jika struktur kelenjar
5\%-50\%. ${ }^{7}$ Stadium adenokarsinoma kolorektal dinilai berdasarkan invasi tumor menggunakan klasifikasi Duke. Duke A, jika sel tumor terbatas pada mukosa, submukosa dan muskularis propria, tanpa invasi ke serosa. Duke B, jika sel tumor telah menembus muskularis propria sampai ke serosa. Duke C, sel tumor telah bermetastasis ke kelenjar getah bening regional. Duke D, jika sel tumor telah bermetastasis jauh. ${ }^{8}$

Dilakukan pengumpulan blok parafin yang berasal dari 40 sediaan tersebut dan dilakukan pewarnaan HE dan imunohistokimia memakai antibodi anti-CD34. Ekspresi CD34 dinyatakan positif berdasarkan warna coklat pada sel-sel endotel dengan atau tanpa lumen yang jelas terpisah dari pembuluh darah yang berdekatan. Penghitungan sel yang imunoreaktif dilakukan di bawah mikroskop cahaya dengan pembesaran 400x, dihitung sel rata-rata yang terwarnai pada lima tempat. Pewarnaan CD34 dilakukan dengan mempergunakan monoclonal antibody anti-CD34 (BI-3C5, Santa Cruz Biotechnology inc).

Blok parafin yang telah dikumpulkan tersebut dipotong memakai mikrotom dengan ketebalan $4 \mu \mathrm{m}$, diletakkan pada object glass yang telah dilakukancoating,kemudiandilakukanpewarnaan imunohistokimia dengan menggunakan metode avidin-biotin. Dilakukan deparafinisasi dengan xilol selama $3 \times 5$ menit, rehidrasi dengan etanol selama 3x5 menit, kemudian dengan alkohol $90 \%, 80 \%, 70 \%$, dan diinkubasi dengan hidrogen peroksidase 3\% selama masing-masing 5 (lima) menit. Bilas dengan akuades, lakukan antigen unmasking retrieval dengan bufer sitrat yang mendidih selama $2 \times 5$ menit. Dinginkan dalam suhu ruangan selama 15 menit. Inkubasi dengan $\mathrm{H}_{2} \mathrm{O}_{2} 0,3 \%$ dalam metanol selama 10 menit. Bilas dengan phosphat buffered saline (PBS). Teteskan blocking serum 1,5\%, inkubasi selama 5-10 menit. Teteskan antibodi primer (CD34) dengan pengenceran 1:100, inkubasi selama 60 menit. Bilas dengan PBS selama 3x5 menit. Teteskan antibodi sekunder dari Novostatin universal, inkubasi selama 10 menit. Teteskan kromogen, inkubasi selama 5-10 menit. Cuci dengan air mengalir selama 5 menit. Inkubasi dalam mayer hematoxylin selama 2 menit. Cuci dengan air mengalir. Dehidrasi dengan alkohol 70\%, 80\%, $90 \%$, etanol selama 3 menit. Masukkan ke dalam xilol, kemudian dilakukan mounting. Data yang diperoleh dianalisis mempergunakan Spearman Coefficient of Rank Correlation.

\section{Hasil}

Dari 40 kasus, usia penderita antara 24 sampai 80 tahun, terdiri atas 16 laki-laki dan 24 perempuan. 
Tabel 1 Karakteristik Penderita

\begin{tabular}{lc}
\hline Usia rata-rata & $48(24-80)$ \\
Laki laki & 16 \\
Perempuan & 24 \\
Lokasi & \\
Kolon asenden & 13 \\
Kolon transversum & 1 \\
Kolon desenden & 5 \\
Rektosigmoid & 21 \\
Gradasi histopatologi & \\
Well differentiated & 13 \\
Moderately differentiated & 16 \\
Poorly differentiated & 11 \\
Stadium (Duke) & \\
Duke A & 17 \\
Duke B & 8 \\
Duke C & 14 \\
Duke D & 1 \\
\hline
\end{tabular}

Gradasi (derajat) tumor yang terdiri atas well differentiated, moderately differentiated, dan poorly differentiated berturut-turut sebanyak 13, 16, dan 11 kasus. Stadium tumor terdiri atas Duke
A, Duke B, Duke C, dan Duke D berturut-turut 17, 8, 14, dan 1 kasus. Jumlah pembuluh darah kapiler/LPB rata-rata 24 (9-38).

\section{Pembahasan}

Angiogenesis merupakan proses pertumbuhan dan proliferasi pembuluh darah. Proses ini dapat terjadi pada jaringan normal, termasuk pada embriogenesis, postnatal dan menjadi aktif pada jaringan yang bertumbuh cepat, termasuk tumor yang solid. ${ }^{14,15}$ Angiogenesis itu penting pada berbagai proses fisiologi dan patologi, dapat terjadi pada pertumbuhan dan diferensiasi, juga penyembuhan luka, peradangan kronik, serta neoplasia., 9,16,17 Angiogenesis diperlukan untuk asupan nutrisi tumor tersebut. ${ }^{10}$ Pertumbuhan tumor $>1-2 \mathrm{~mm}$ bergantung pada pembentukan pembuluh darah baru. ${ }^{10,14}$ Diameter tumor tidak dapat melebihi $1-2 \mathrm{~mm}$ bila sedikit vaskularisasi, oleh karena terjadi hipoksia yang menyebabkan kematian sel-sel. ${ }^{10}$ Angiogenesis yang berasal dari endothelial progenitor cells (EPCs) yang dimobilisasi dari sumsum tulang, bermigrasi ke tempat luka atau pertumbuhan tumor. Di tempat tersebut EPCs berdiferensiasi dan membentuk jaringan yang matur dan berhubungan dengan pembuluh darah yang sudah ada. ${ }^{9}$ Angiogenesis pembuluh darah yang sudah ada, sel endotel pembuluh darah tersebut akan menjadi motil

Tabel 2 Hubungan Imunoekspresi CD34 dengan Gradasi Adenokarsinoma Kolorektal

\begin{tabular}{cccc}
\hline $\begin{array}{c}\text { Jumlah Rata-Rata } \\
\text { Pembuluh Darah } \\
\text { Kapiler/ LPB }\end{array}$ & Well Differentiated & Moderately Differentiated & Poorly Differentiated \\
\cline { 2 - 4 } & - & - & 1 \\
$11-20$ & 7 & 6 & 4 \\
$21-30$ & 2 & 5 & 4 \\
$31-40$ & 4 & 5 & 3 \\
\hline
\end{tabular}

Keterangan: $\mathrm{p}<0,005$

Tabel 3 Hubungan Imunoekspresi CD34 dengan Stadium (Duke) Adenokarsinoma Kolorektal

\begin{tabular}{ccccc}
\hline $\begin{array}{c}\text { Jumlah Rata-Rata } \\
\text { Pembuluh Darah } \\
\text { Kapiler/LPB }\end{array}$ & A & B & C & D \\
\cline { 2 - 5 } & - & 1 & - & - \\
$11-20$ & 8 & 7 & 2 & - \\
$21-30$ & 2 & 6 & 2 & - \\
$31-40$ & - & 1 & 9 & 1 \\
\hline
\end{tabular}

Keterangan: $\mathrm{p}<0,01$ 
Tabel 4 Nilai Korelasi Gradasi atau Stadium dengan CD34

\begin{tabular}{lccccc}
\hline & $\mathbf{r}_{\mathrm{s}}$ & t Hitung & t Tabel & Sifat & $\mathbf{p}$ \\
\hline Gradasi & 0,18 & 0.89 & 2,07 & Non-sign & 0.38410611 \\
Stadium & 0,83 & 7.24 & 2,07 & Sign & $2.2929 \mathrm{E}-07$ \\
\hline
\end{tabular}

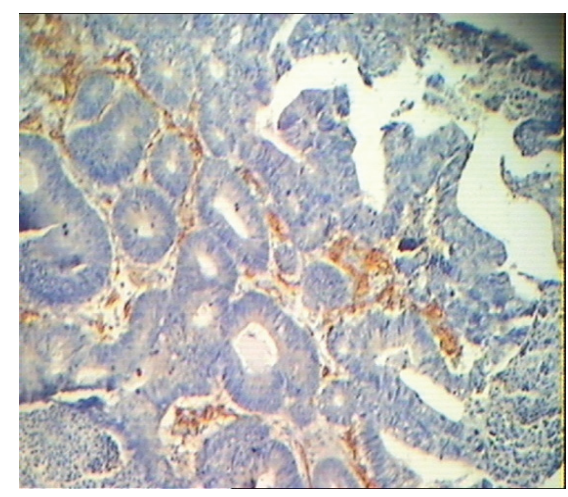

A

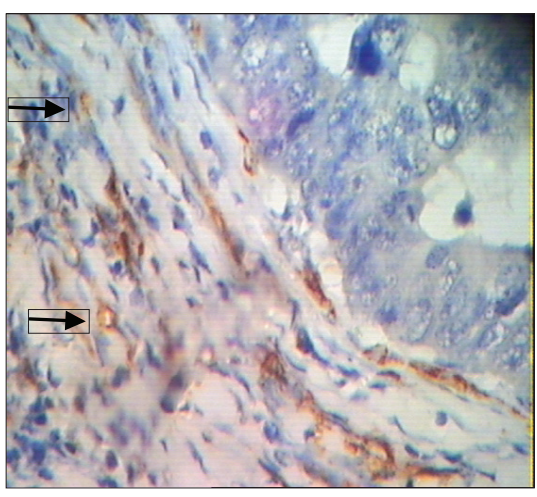

B

Gambar Ekspresi CD34 pada Adenokarsinoma Kolorektal Moderately Differentiated

A pada pembesaran 100x dan B pada pembesaran 400x. Anak panah menunjukkan neovaskularisasi

serta berproliferasi membentuk tunas kapiler. Pada awal mekanisme maturasi pembuluh darah tersebut melibatkan perisit dan sel otot polos untuk membentuk lapisan periendotel. ${ }^{9}$

Dari 40 kasus penelitian adenokarsinoma kolorektal yang diperiksa memakai pewarnaan imunohistokimia dengan monoklonal antibodi anti-CD34, didapatkan hasil MVD tertinggi pada gradasi dua atau moderately differentiated sebesar $46 \%$ dan pada stadium Duke C sebesar 87,5\%. Pada well dan poorly differentiated, MVD lebih rendah bila dibandingkan dengan moderately differentiated.

Setelah diuji secara statistik dengan Spearman Coefficient of Rank Corelation, korelasi gradasi tumor dengan CD34 sebesar 0,182 yang bersifat belum bermakna dengan $t$ hitung sebesar 0,89 . Hal ini berbeda dengan hasil penelitian Sharifi dkk. ${ }^{10}$ MVD memperlihatkan hubungan yang ternyata signifikan dengan gradasi histopatologi. Perbedaan ini dapat disebabkan karena beberapa faktor, antara lain pemeriksaan serta penilaian derajat atau gradasi karsinoma kolorekal, jenis marker sel untuk endotel yang dipergunakan, dan bidang pembesaran dalam menghitung jumlah pembuluh darah baru.

Korelasi antara stadium tumor dan CD34 sebesar 0,834 yang bermakna secara statistik dengan thitung sebesar 7,24 yang lebih besar dari t tabel $=2,07$ untuk alfa $95 \%$. Hal ini sesuai dengan penelitian $\mathrm{Li}$ dkk. ${ }^{12}$ yang melaporkan korelasi MVD dengan kedalaman invasi dan metastasis. Sharifi dkk. ${ }^{10}$ menyatakan hubungan antara microvascular density (MVD) dengan gradasi histologi dan stadium penyakit. Beberapa penelitian membuktikan korelasi yang signifikan MVD dengan invasi dan juga metastsasis pada berbagai tumor solid seperti tumor payudara, paru, uterin, serviks dan prostat, tetapi hubungan ini masih kontroversi pada karsinoma kolorektal. Menurut Malik dkk. ${ }^{5}$ Prat dkk., ${ }^{6} \mathrm{Li}$ dan Harris, ${ }^{15}$ Li dkk. ${ }^{12}$, Cristi dkk., ${ }^{16}$ van Beijnum dkk., ${ }^{17}$ Tarta dkk., ${ }^{18}$ peningkatan vascular density berhubungan dengan insidensi metastasis yang tinggi serta prognosis yang buruk.

Simpulan, terdapat hubungan MVD dengan kedalaman invasi dan metastsis tumor ke kelenjar limfe yang dinilai dengan klasifikasi Duke, CD34 potensial dipakai untuk memprediksi prognosis, memperkirakan kemungkinan metastasis melalui pembuluh darah, dan juga memprediksi respons terhadap terapi antiangiogenik.

\section{Daftar Pustaka}

1. Rosai J. Rosai and Ackerman's surgical pathology. Edisi ke-10. Edinburgh: Mosby; 
2011.

2. Abdullah M, Sodoyo AW, Utomo AR, Fauzi A, Rani AA. Molecular profile of colorectal cancer in Indonesia: is there another pathway? Gastroenterol Hepatol Bed Bench. 2012;5(2):71-8.

3. Ferlay J, Shin HR, Bray F, Forman D, Mathers C, Parkin DM. Estimates of worldwide burden of cancer in 2008: GLOBOCAN 2008. Int J Cancer. 2010;127(12):2893-917.

4. Belur LR, Prodetz-Pedersen KM, Sorenson BS, Hsu AH, Parker JB, Carlson CS, dkk. Inhibition of angiogenesis and supression of colorectal cancer metastatic to the liver using the Sleeping Beauty Transposon System. Mol Cancer. 2011;10(1):14.

5. Malik A, Mishra RN, Fanthome B, Ramesh R, Patrikar SR. Role of CD34, vascular endothelial growth factor, and p53 in neoangiogenesis as correlated with stage of disease in colorectal carcinoma. MJAFI. 2011;67(4):320-5.

6. Prat A, Casado E, Cortes J. New approaches in angiogenic targeting for colorectal cancer. World J Gastroenterol. 2007;13(44):5857-66.

7. Hamilton SR, Aaltonen LA. Tumor of the colon and rectum. Dalam: World Heath Organization Classification of Tumours. Pathology and genetics of tumor of the digestive system. Lyon. IARC Press. 2010. hlm. 131-56.

8. Fenoglia CM. Gastrointestinal pathology, penyunting. Edisi ke-3. Lippincott Williams \& Wilkins;

9. Kumar V, Abbas AK, Fausto N. The gastrointestinal tract. Dalam: Turner, JR, penyunting. Robbins and Cotran pathologic basis of disease, penyunting. Edisi ke-8. Philadelphia: Elsevier Saunder; 2010. hlm. 763-831.

10. Sharifi N, Ghaffarzadegan K, Ayatollahi H, Shakeri MT, Sadeghian MA, Azari JB. Evaluation of angiogenesis in colorectal carcinoma by CD34 immunohistochemistry method and its corelation with clinicopathologic parameters. Acta Med Iran. 2009;47(3):161-4.

11. El-Moneim NA, Ebid SAE, Kazem A, Saad A, Mousa S, El-Abd E, dkk. The role of angiogenesis assessment in the prognosis of breast carcinoma and in the evaluation of the therapeutic effect of "shark care" drug as an angiogenesis inhibitor. Turk J Cancer. 2008;38(3):123.

12. Li ZP, Meng QF, Sun CH, Xu DS, Fan $\mathrm{M}$, Yang XF, dkk. Tumor angiogenesis and dynamic CT colorectal carcinoma: radiologic-pathologic correlation. World J Gastroenterol. 2005;11(9):1287-91.

13. Qasim BJ, Ali HH, Hussein AG. Immunohistochemical expression of PCNA and CD34 in colorectal adenomas and carcinomas using specified automated cellular image analysis system: a clinicopathologic study. Saudi J Gastroenterol. 2012;18(4): 268-76.

14. Fragou EM, Lawson J, Kanthan R. Angiogenesis in male breast cancer. World $\mathrm{J}$ Surg Oncol. 2005;3(1):16.

15. Li WW, Harris RE. The Angiogenesis Foundation. Angiogenesis inhibition in the prevention of colorectal cancer. Targeting Tumor Angiogenesis Fall. 2009.

16. Cristi E, Perrone G, Toscano G, Verzi A, Nori S, Santini D, dkk. Tumour proliferation, angiogenesis, and ploidy status in human colon cancer. J Clin Pathol. 2005;58:1170-4.

17. van Beijnum JR, Dings RP, van der Linden E, Zwaans BM, Ramaekers FC, Mayo KH, dkk. Gene expression of tumor angiogenesis dissected: spesific targeting of colon cancer angiogenic vasculature. Blood. 2006;108(7):2339-48.

18. Tarta C, Teixeira CR, Tanaka S, Haruma K, Chiele-Neto C, da Silva VD. Angiogenesis in advanced colorectal adenocarcinoma with special reference to tumoral invasion. Arq Gastroenterol. 2002;39(1):32-8.

19. Xiong B, Sun TJ, Yuan HY, Hu MB, Hu WD, Cheng FL. Cyclooxygenase-2 expression and angiogenesis in colorectal cancer. World J Gastroenterol. 2003;9(6):1237-40.

20. Kuroda N, Nayakama H, Miyazaki E, Toi M, Hiroi M, Enzan H. The distribution of CD34positive stromal cells and myofibroblasts in colorectal carcinoid tumors. Histol Histopathol. 2005;20(1):27-33. 